\title{
Avrupa Seyahat Edebiyatı ve Osmanlı Coğrafyasında Bir Seyyah: Charles Mac Farlane
}

\author{
Muhuttin DOĞAN*
}

\section{$\ddot{O ̈ z}$}

Seyahat, insanlara geniş bir dünyanın kapılarını açar; çünkü sürekli aynı yerde yaşamak, insanları bir mekân kuşatmasının içerisine alır. Bu şekilde yaşayan insanlar, bütün dünyayı kendi yaşadıkları çevreden ibaret sanarak bir körleşmeyle yüz yüze kalırlar. Böylelerinin bilgilerinden, konuşmalarından ziyade, gezip görmüş insanların anlattıkları, daha ilgi çekici gelir çevresindekilere.

Dünyanın bilinmeyen noktalarını keşfetmek her toplum için bir merak unsuru olsa da zamanla Batı dünyası, bu alanda büyük bir üstünlük yakalar ve uzak ülkelerden seyyahlar, yanlarında kıymetli bilgilerle dönerler "öteki" hakkında. Her seyyahın anlattıkları, diğer maceraperestlerin aklına seyahat etme arzusunu düşürür. Böylece kara veya deniz yolu ile çok sayıda seyyah yollara çıkar farklı kültürlerin sihirli yaşamlarını ve coğrafyalarını keşfetmek için. Fakat başlangıçta masumane bir keşif arzusuyla başlayan seyahatler, 18 ve 19. yüzyıllarda şekil değiştirmeye başlar. Seyahat masum bir eylem olmaktan çıkarak elde edilen bilgiler sayesinde ötekine hükmetme vasıtası haline gelir, daha da ileri gidilerek diğer kültürlere ait birçok değer yerlerinden edilerek Batı'ya taşınır. Seyahatlerin onlara sunduğu imkânlar sayesinde dünyanın diğer bölgelerindeki ülkelerle aralarındaki gelişmişlik farklarını kendi lehlerine arttırarak 19. yüzyılla birlikte zirveye ulaşırlar.

Yerkürenin önemli coğrafyalarını ellerinde bulunduran Osmanlı ülkesi de uzun süredir ilgi alanlarındadır; ama artarak devam eden bu ilgi Osmanlının zayıf olduğu 19. yüzyılda kendisini daha fazla hissettirir. Artık İstanbul ve imparatorluğun diğer önemli bölgeleri amaçları sadece seyahat olmayan seyyahların akınına uğrar.

Bu çalışmada; başlangıçta yüzyıllara göre amaçları ve şekli değişerek günümüze kadar devam eden Avrupa Seyahat Edebiyatı hakkında temel bilgiler verilecek, sonra da 19. yüzyılın ilk yarısında, Yunan İsyanı ve Tanzimat süreci gibi önemli dönemlerde, Osmanlı coğrafyasında bulunarak gözlemlerinden oluşan dört ciltlik kitap yazan C. Mac Farlane'in eserlerinde, Türk, Rum, Ermeni ve Yahudi toplumlarına yaklaşımı ve onları nasıl yansıttığı üzerinde durulacaktır.

Anahtar Kelimeler: Avrupa seyahat edebiyatı, Osmanlı coğrafyası, Mac Farlane, önyargı.

* Dr. Öğretim Üyesi, Afyon Kocatepe Üniversitesi, Fen Edebiyat Fakültesi, Türk Dili ve Edebiyatı Bölümü, Afyon, Türkiye.

Elmek: dogan.muhittin@hotmail.com

Orcid: 0000-0002-3525-5981 


\title{
European Travel Writing and a Traveller in the Ottoman Territories: Charles Mac Farlane
}

\begin{abstract}
Travelling opens the doors of a wide world to the people as living constantly in the same place makes people get stuck in an area. People who live in this way are blind to this, thinking that the whole world is similar to their surroundings. Rather than what these people know and talk about, those around are more interested in what the ones who have travelled to a lot of places tell.

Although exploring the unknown corners of the world has been attractive for all communities, the Western world had been ahead of and thus more advantageous than the others in this and travellers from remote countries turned back with valuable information about "the other". What each traveller told made other adventurers wish to travel. Therefore, many travellers set out and travelled by land or sea to explore the magic lives and geographies of different cultures. However, journeys which had started over a naive desire for exploration, started to change in the 18th and 19th centuries. Travelling was not just for adventure anymore but became a way of dominating the other and a way of bringing most of the values belonging to other cultures to the West. Thanks to the opportunities travelling offered, they developed more than the countries in the other parts of the world and reached their peak in the nineteenth century.

The Ottoman Empire which possessed and controlled important parts of the world had long attracted the attention of the Europeans; however, this growing interest towards the Ottoman Empire was felt more and more in the nineteenth century, when the Ottomans were the weakest. Now Istanbul and the other important regions of the Empire were flooded by travellers who had other purposes than just traveling. In this study, firstly some basic information about European Travel Writing which has survived up to the present day changing its aims and shape throughout the centuries will be given. Then, how C. Mac Farlane, who wrote a four-volume book out of his observations in the Ottoman territories during important periods such as the Greek Rebellion and the "tanzimat" reform era, reflects and approaches the Turkish, Greek, Armenian and the Jewish societies will be studied.
\end{abstract}

Keywords: Western Travelers, Ottoman Empire, C. Mac Farlane, prejudice, travelogue. 


\section{Extended Summary}

Although exploring the unknown corners of the world has been attractive for all communities, the Western world had been ahead of and thus more advantageous than the others in this and travellers from remote countries turned back with valuable information about "the other". Therefore, many travellers set out and travelled by land or sea to explore the magic lives and geographies of different cultures. However, journeys which had started over a naive desire for exploration, started to change in the $18^{\text {th }}$ and $19^{\text {th }}$ centuries. Travelling became a way of dominating the other and a way of collecting information about the "other".

19th century became a turning point for the West because the technological advances helped them to dominate the world easily. Due to the advances in all areas, ways of the travelling had also changed. Thanks to the steamships and new train routes built by colonialists, people were able to reach the magical East they desired to see in a safer and faster way. Alexandria-Cairo and Cairo-Asia line; Izmir-Aydın and Istanbul line provided comfortable and irresistible travel opportunities. With the improvements in the conditions, travelling, which used to be difficult and required many equipment, became a more practical and faster attempt that required less time.

The Ottoman Empire which possessed and controlled important parts of the world had long attracted the attention of the Europeans; however, this growing interest towards the Ottoman Empire was felt more and more in the nineteenth century, when the Ottomans were the weakest. Now Istanbul and the other important regions of the Empire were flooded by travellers who had other purposes than just traveling.

During this period, C. Mac Farlane set out with the aim of visiting the Ottoman geography, where he came twice in twenty years, from a different point of view than the other travellers. After stating that each traveller from different countries mirrors a part of the vast Ottoman world, the writer emphasizes that he deserves particular importance in terms of his arrival time and the information he provided in 
his work as he was there during very critical periods of the empire. During the nineteenth century, while the Empire was experiencing some great disasters alongside with the joys, it was one of Mac Farlane's main goals to closely witness the period and learn about the thoughts of the Muslims and to provide the truest information about them for the service of Britain, which was at the top of its power then. Instead of being an ordinary traveller, throughout his work the author positions himself as the "seeing eye" of a large country with ambitions to spread to distant lands.

Mac Farlane states that he did not even consider revisiting an empire dying in pain after he witnessed in his first visit the injustices and bad governments. However, he was convinced by an Ottoman bureaucrat that some great reforms were made by the Sultan Abdülmecid and the grand vizier Mustafa Reşid Pasha. Thus, after a twenty-year hiatus, he decided on his new journey, which would take eleven months, to see whether there was indeed equality between Muslims and non-Muslims and to witness whether the mismanagement, persecution and bribery were put to an end. On this journey, he drew more attention to the lives of different nations living in the Ottoman country.

According to the author, after Tanzimat reform era, the Turks living in Istanbul were more docile and more civilized than the previous periods. With the effect of the reforms, there were no traces of the old arrogant Turks with their tight pants and coats buttoned up to the collar. The Turk, who was easily known for his haughty look, distinctive clothing and bully walk, had lost all of these features one by one in the newly created environment. The Turks spent most of their days smoking various tobaccos in coffee shops. They had a very slow_life. Sitting silent for hours was one of their characteristic features. They were people who do not work hard after gaining a higher position and became fat quickly due to their immobility. Bribery was also a common habit in their lives.

Although Greeks had a great civilization of their own in history, this nation had always felt the pressure of the Iranians and Ottomans, the two great powers of Asia. The life of the Greeks, who lived in peace in Izmir, and their distinctive lifestyle changed after the 1822 Greek Rebellion. Although they did not go far from their joyful lives and traditional entertainments, there was no trace of their old rich lives. 
There was not much difference in the lifestyle of Armenians, who were in different parts of the empire. Their lifestyle was in line with that of the Turks, and they ate their food on the table, but instead of using tools such as forks and knives, their dirty hands and fingers were their greatest helpers. Outside the house, only the eyes of their women could be seen. At home, women were treated as if they were a servant rather than a wife. The language they used both in the family and in the bazaar was Turkish rather than their own language.

He states that one of the most despised communities in the Ottoman geography was the Jews. They mostly lived by doing the work of others. They always preferred to stay away from military, war and agricultural affairs. It was difficult to see them working in the soil with agricultural tools. One of the most distinctive features of the Jewish community, which has different clothing styles like other communities, was that they were too cowardly. 



\section{Giriş}

İnsanlar, asırlar boyunca kendi dışındaki dünyaları merak etmiş, o dünya ile ilgili bilgilere ulaşabilmek için türlü güçlükleri göze alarak yolculuklara çıkmışlardır. Yurdundan ayrılan seyyah, ülkesinin gören gözleri olabilmek için karşılaştığı yeni yerleri büyük bir dikkatle inceleyip notlarını alarak ciddi bir birikimle dönmek zorundaydı ayrıldığı vatanına. Toplumlar her zaman seyyahların anlattıklarını ilgiyle dinlemişler, onların yazdıkları kitaplar, çok satanların hep başında gelmiştir. Belli bir zamana kadar ötekinin hayatları, şehirleri, coğrafyaları, günlük yaşamaları, kadınları, zenginlikleri ve eğlenceleri hakkında bilgiye ulaşmanın ana kaynağı seyahat yazıları ve anlatıları olur.

Seyahat alanında asırlarca öncülüğü ellerinde tutanlar sürekli Batılı toplumlar olur. Dünyanın bilinmeyen bütün alanları, gizli kalmış köşeleri onlar için keşfedilecek yerlerdir. Seyahat ve keşfetme arzusu, Batılı ülkelere diğerlerinden farklı üstünlükler sağlar. Seyahatlerin onlara sunduğu imkânlar sayesinde dünyanın diğer bölgelerindeki ülkelerle aralarındaki gelişmişlik farklarını kendi lehlerine arttırarak 19. yüzyılla birlikte zirveye ulaşırlar. Yerkürenin önemli coğrafyalarını ellerinde bulunduran Osmanlı ülkesi de uzun süredir ilgi alanlarındadır; ama artarak devam eden bu ilgi Osmanlının en zayıf olduğu 19. yüzyılda kendisini daha fazla hissettirir. Artık İstanbul ve imparatorluğun diğer önemli bölgeleri amaçları sadece seyahat olmayan seyyahların akınına uğrar.

Oluşturulan seyahatnameler sayesinde, Doğu'nun dünyasına yeni pencereler açılarak toplumlar arasındaki duvarlar yıkılmaya çalışılır. Aynı süreçte bir taraftan eski duvarlar yıkılırken; diğer taraftan art niyetli ve ön yargılı seyyahların sebep olduğu hayali kalın duvarların oluşturulduğu sınırlar ortaya çıkar.

Bu çalışmada; ilk olarak yüzyıllara göre amaçları ve şekli değişerek günümüze kadar devam eden Avrupa Seyahat Edebiyatı hakkında temel bilgiler verilecek, sonra da yirmi yıl arayla Osmanlı ülkesine iki defa gelen ve orada uzun seyahat şanslarına sahip olan İngiliz seyyah C. Mac Farlane'nin eserlerinden yola çıkılarak, Batının Osmanlı insanına yaklaşımlarına kısaca ışık tutulmaya çalışılacaktır. 


\section{Avrupa ve Seyahat Kültürü ${ }^{1}$}

Bir zamanlar insanlar, sadece seyahat etmek için seyahat ederdi. Uğruna akla hayale gelmez güçlükleri göze aldıkları yolculuk serüveni, eğitimin, bilginin, kültürlenmenin vazgeçilmez bir parçasıydı. Bilinmeyen dünyalara yapılan yolculuklar gezgine, başkalarıyla yüzleşme, onu görüp tanıma deneyimi sunardı. Böylece seyyah, sadece “ötekini” anlayıp anlamlandırma yetisini kazanmaz, aynı zamanda kendine ve içinden çıktığ 1 toplumun dünyasına, seyahatle uzaktan bakma şansını yakalayarak bir üstünlük elde ederdi, yerinde oturan yurttaşlarına karşı (Şirin, 2013: 176). Ülkesine dönen seyyah, etrafındakiler tarafından ayrıcalıklı bir kişi olarak karşılanır ve onlar için farklı coğrafyalardan haber veren, dünyanın sadece kendi yaşadıklarından ibaret olmadığını akıllara düşüren, yeni büyülü dünyalara açılmalarını sağlayan bir yol gösterici olur.

Avrupalı öncü gezginler, karşılaştıkları dünyaları belirli kalıpların içerisine yerleştirdiklerinden, haleflerinden ancak çok azı, önyargılarla örülmüşs kalıpların dışına çıkabilmeye çalışırlarsa da pek başarılı olamazlar. Önyargıların en büyük mağduru, Doğu ve İslam dünyası olur. O dünyanın insanları, seyahatnamelerde 'kirli, çirkin, aptal ve sıkıcı' insanlardır. Onlarla ilgili bilgiler de güçlü bir taraf tutmanın ve uydurmanın etkisinde kalmış lekeli bir bilgidir (Kabbani, 1993: 9899). Bu tutumlar yüzünden, asıl amacı dünyanın bilinmeyen bölgelerini gözler önüne sermek olan seyahatnameler, bugün bile etkilerinden kurtulamadığımız kolonici görüşlere hizmet eden bilgilerle doludur. Bu durumdan rahatsızlı̆̆ını dile getiren Billie Melman, önyargıların dışına çıkabilirsek, "Avrupalıların ufkunu genişleten gezi yazılarının en önemli faydalarından birinin de kültürler ve toplumlar arası karşılaştırmalara zemin hazırlayarak, kendimizi ve ötekini daha iyi anlamlandırmamıza yardımcı olduğunu (Melman, 1992: 9)" görebileceğimizi vurgular.

İlk dönem yazar ve okuyucularının birincil önceliği, edebî değerleri yüksek yapıtlarla yüz yüze gelmek yerine; yeni bilgilerle dolu aydınlatıcı seyahat dokümanlarıyla mutlu olmaktı. Onlar için bilgi ve yeryüzünün fiziki keşfi her şeyden önemliydi. Özellikle Sir Francis Bacon'un seyyahlarl, bilgilendirmeye 
devam etmeleri ve gittikleri bölgelerin dillerini öğrenmeleri konusunda uyarlar (Thomson, 2011: 43) da bilinmeyen farklı dünyaların Avrupalı okurlara sunulmasında etkili olur. Elde edilen bilgiler sayesinde, Fransa, İngiltere, daha sonra Hollanda, deniz aşırı ülkeleri, kolonilerine katma yarışına girer, bunun yanında Hıristiyan dünya da uzak diyarlardaki insanlara kendi dinlerini benimsetebilmek için seyahatin her türlü zorluklarını göze alır.

On beş ve on altıncı yüzyıllar, Doğulular için büyük Müslüman imparatorluklar çă̆ıydı (Hindistan, İran, Memluk ve Osmanlı). İstanbul'u alarak onların yanı başlarına kadar gelen, Hıristiyan dünyasına bir kuşatılma ve yok olma korkusu salan Osmanlı Devleti (Irwin, 2088: 65-66), artık Avrupa'nın en büyük endişelerinden biridir. Avrupa, karşılarında bulunan ve kendilerini İslam'ın temsilcileri olarak sunan yeni devleti, daha yakından, objektif olarak tanımak amacıyla, geniş bir seyahat yelpazesi oluşturur. Bunun sonucu olarak onların örfleri, adetleri, askerî, siyasi yapıları; hatta hayvan toplulukları ve bitki çeşitleri de seyyahların ilgi alanlarına girer. Farklı bakış açısıyla İslamî Şark (Osmanlı üzerinden), Batılının gözünde yeniden yorumlanmaya başlanır. Bu yorumlama sürecinin altında 'Hıristiyan Batı'nın kendi üzerine düşünme ve kendisini ıslah etme isteğinin etkisi de vardır' (Bulut, 2010: 59). Bunun sonucu olarak İslam'1 karalamak yerine, içinde bulundukları sıkıntılardan kurtulmak amacıyla, karşılarındaki toplumun üstünlüklerinden faydalanma yolu tercih edilir.

Batı'da, yabancı ülkeleri tanıma, 17. asırda bir devlet politikası haline gelir. Hem kendi isteğiyle hem de devlet desteğiyle yola çıkan seyyahların oluşturduğu Doğu'yla ilgili seyahat eserlerinin sayısı, iki yüzü geçer. Seyahatnamelerde anlatılanlar, Batı zihnindeki Şarka karşı bir tutku yaratır ve daha fazla gezginin, kendi dünyalarından tamamen farklı, gizemlerle dolu bu dünyaya yönelmelerini sağlar. Seyahatnamelerin gördüğü aşırı ilgi editörleri harekete geçirir, bazı gezi yazıları, okuyucunun ilgisini daha fazla çekebilmek amacıyla, yeniden düzenlenir. Böylece oluşan ticari hacme paralel olarak, dil bilen insanlara ihtiyaç artar ve bunu karşılamak için Cambridge, Oxford gibi Doğu araştırmaları yapan kürsülerin sayıları da çoğalmaya başlar.

Aydınlanma dönemi (18.yy) Avrupası, dinin katı kurallarından kurtulmuş, dogmatik bilgilerden uzak, akılcı, ilerici, laik ve özgüveni yüksek bir Avrupa’ydı. 
Karşılarında, geçmiş yüzyıllarda kâbusları olmuş bir Müslüman Doğu veya Osmanlı yoktur artık. Onun yerine gücünü kaybetmiş, egzotik, durgun, uygarlıktan nasibini almamış, tuhaf kıyafetleriyle (Lowe, 1991: 30-31) Batıya muhtaç; hatta onun elinde, yeniden şekillenmeye hazır, tarihiyle, kültürüyle, medeniyeti ile koskoca bir İslam dünyası durmaktadır. Batı, kendini üstün görmenin ve gücün verdiği özgüvenle, önündeki durağanlaşmış dünyayı, eski ön yargılarından uzak, entelektüel birikimleriyle yeniden yorumlamaya hazır olduğundan emindir:

“Doğu, Avrupa'nın çeşitli amaçlar için kullanacağ bir kavramsallaştırmaya ve dolayısıyla da şeyleştirmeye maruz kalacaktır: Tecessüs, bilgi, egzotizm ve ayılama nesnesi. Daha sonra da bir mukayese malzemesi. Artık, uygulanan bask -var olduğu oranda-yapısal ve entelektüel niteliklidir: Avrupa'nın Doğu'da çoktandır liman acentelikleri, tüccarları, elçileri, seyyahları, casusları vardır ve çok geçmeden bilginleri de olur (Bulut, 2010: 72)."

Aydınlanma çağı, Avrupa'nın iki bin yıldır süren kültürel gelişmesinin zaferle sonuçlandığı bir yüzyıl olur. Çünkü bilim ve uygarlık alanında yaşanan gelişmeler, eskiden beri modernistler ve gelenekçiler arasında yaşanan kavgaları, yenilikçiler lehine sonuçlandırır (Porter, 1991: 18). Gelişmelerin kaçınılmaz sonucu olarak Avrupa'nın, zamanla dünyanın en uzak bölgelerine bile yayılarak, oralardaki kalıcılıklarını pekiştirdiklerine şahit olunur. Keşifler yüzyılı olarak kabul edilen bu süreçte toplumun değişik katmanlarından gelen -gemici, filozof, araştırmacı, sanatçı, asker vb.- seyyahların ortaya koyduğu bütün dokümanlar, bir yönüyle mutlaka aydınlanma çağının değirmenine su taşımak zorundaydı ve öyle de oluyordu. Elde edilen geniş bilgi yığınıyla Doğu ile ilgili kalıcı ön yargıların oluştuğu bir döneme de girilmiş olur ve İslam dünyası onlar için geri kalmış bir kültürün temsilcisidir artık.

1798'de Napolyon'un Misırı ele geçirmesine paralel olarak Müslüman Doğu, hem kadın hem erkek gezginler tarafından ayrı bir önem arz etmeye başlar. Akdeniz Oryantalizmi denilen yeni bir fenomen, Avrupa kültürünün olmazsa olmazları arasına girer. Avrupalı gezginler, Doğuyu sadece kitaplarıyla yurttaşlarının gözlerinin önüne sermenin yanında; resimler, skeçler, rehber kitaplar, fotoğraflarla da ayrı bir zenginlik katarlar tanıtımlarına. Yayıncıların ana dayanağı ve en büyük gelir kaynağı -Müslüman Doğu üzerine yapılan çalışmaların okuyucula- 
rın muhayyilesinde büyük bir yer bulması sayesinde- bu gizemli dünyaları anlatan eserler olmaya başlar. Doğuya doğru halkın artan ilgisi, sadece o alanda yazılanları okumaktan ibaret olmaktan çıkarak geliri yerinde, biraz da macera düşkünü insanların, turlar halinde Doğu yolculuklarına katılmalarını da sağlar. Özellikle Ortadoğu seyahati, Avrupalı elitler için sadece bir seyahat olmaktan çıkar ve onların eğitimlerinin bir parçası haline gelir. Görece üstünlüğünü hiç bozmadan Şarkla karmaşık ilişkiler içerisinde, kendisine esnek bir konum sağlayan Batı, bu coğrafyalarda ciddi bir direnişle, karşı koymayla yüz yüze gelmeden oralarda bulunma ve Şarkın dünyasını yorumlama imkânlarına sahip olur.

Doğu gezisine çıkan romantizmin etkisindeki her yazar kendine göre bir Doğu miti yaratır. Z1tlıklarla dolu olması; “orada en korkunç suçlarla en arı bir masumiyet, en affetmez tabularla en çıldırtıcı duygusallık ve yasak zevkler, efendilikle kölelik, kişiliklerde yoğun çelişkiler (çift kişiliklilik) (Parla, 2012: 25)" yaratılan Doğu mitinin değişmeyen özellikleridir. Kişiliklerini bulmak için çıktıkları yolculuklarda romantikler, kendi yarattıkları hayali dünyanın etkisinden kurtulamayarak gerçeklerle yüzleşmekten de kaçınarak Doğu gerçekleriyle tam örtüşmeyen, kişisel özlemleriyle yoğrulmuş, değiş̧meyen bir yığın egzotik külliyatla, ülkelerindeki okuyucuların hayallerini süslerler. Doğuyu tam anlamıyla kavrayamamak, sadece romantizmin etkisiyle buralarda dolaşan yazarların eksikliğinden kaynaklanmamaktaydı şüphesiz; bunun yanında bir de Doğuluların kendi içlerine dönük, kendilerini kolay kolay yabancıya açmayan özelliklerinin de etkileri vardı. Tıpkı kadınlarının peçelerin arkasına saklanması gibi; Şark sadece sözcüklerin değil aynı zamanda sessizliklerin de arkasına saklanılan bir yerdi (Yeğenoğlu, 2003: 68-69).

19. yüzy1l gücünün zirvesine erişmiş Batı için bir dönüm noktası olur, ${ }^{2}$ teknolojik gelişmeler, onların dünyaya daha kolay hâkimiyet kurmasına yardımcı olur. Her alanda görülen ilerlemeler, seyahatin şeklini de değiştirmeye başlar. Gelişen buharlı gemiler ve kolonyalistler tarafından inşa edilen yeni tren yolları sayesinde, insanlar, arzuladıkları sihirli Doğu’ya daha güvenli ve hızlı ulaşabilir-

2 "19. yüzyıl Batı tarihi açısından bir dönüm noktası sayılabilir. Çünkü 19. yüzyıl, Batılı toplumların oryantalizm gibi çeşitli yardımcı kurumlarla yüz yıllar boyunca Doğulu toplumlara karşı yürüttüğü hâkimiyet mücadelesinin Batılı toplumlar lehine olumlu olarak neticelendiği bir yüzyll olmuștur. Batı bu yüzyılda, genelde Doğu özeldeyse İslam toplumları üzerinde sağladığı hâkim pozisyonuyla bir anlamda dünya egemenliğini de eline geçirdiğini ilan etmiştir." (Kenan Çağan (2019), Postmodernizm ve Mahremiyetin Dönüşümü, Pruva Yayınları, Ankara, s. 161.) 
ler. İskenderiye-Kahire ve Kahire-Asya hattı; İzmir-Aydın ve İstanbul hattı, Batılı gezginlere, vazgeçemeyecekleri bir itici güç ve rahatlık sağlar. Koşulların gelişmesiyle birlikte eskiden zorlukları çok fazla olan ve birçok donanım gerektiren tutkulu yolculuk arzusu, daha az zaman isteyen, daha pratik hızlı bir teşebbüs haline gelir (Behdad, 2007: 64).

Önceki dönemlerde görülmeyen seyyahlığın daha az maceralı, daha az tehlikeli ve daha konforlu şekli olan turist topluluklarının yolculuğu, zamanla büyük rakamlara ulaşır. Amaçları ve özellikleri farklı olan insan grupları, daha güvenli olan bu yollarla, hem Avrupa içinde hem Avrupa dişında dolaşmaya başlar; kimisi gördüklerini yüzeysel olarak ele alır, kimisi daha büyük merakla görülmemiş, farklı yer ve kültür peşinde koşar. Viktorya dönemi İngiltere'sinin sıkıcı ahlak kurallarından kurtulup, kendilerini yeni diyarlardaki hayali özgürlüklerin kucağına atmayı düşünenler olduğu gibi; diğer taraftan Nerval ve Flaubert gibi erotik arzular peşinde, yolculuğa çıkanlar da olmaktadır. Turistler için oluşturulan rehber kitaplarının birincil kaynakları da yine daha önce yazılmış Oryantalist seyahatnameler olur ve böylece, Doğu'nun önceki seyyahların açtığı yoldan tanınması, teşvik edilir. Bunların yanında rehber kitaplar, sadece Doğu yolculuğuna çıkacaklar için değil; aynı zamanda evinde, koltuğuna kurulmuş bir yerlere gitme arzusunda olmayan insanlar için de hazırlanır. Onlar da seyahatname okuru gibi evlerinin loş odalarında, rehber kitaplarının ışı̆̆ı altında ‘öteki’nin egzotik dünyalarını ararlar.

Çağlar boyunca, özelliklerinde küçük büyük değişimler göstererek canlılığını sürekli koruyan seyahat, yakın geçmişte daha büyük bir değişimin içerisine girer. İlerleyen teknoloji sayesinde, her şey hızlı şekilde gelişip değişmektedir. Demografik altüst oluşlar, sarsıntılı kentleşmeler, farklı toplulukları birbirlerine bağlayan iletişim sistemleri... Hayatın her alanında baş döndürücü bir değişimle yüz yüze kalınır (Berman, 2017: 28-29). Eski devirlerde yüzlerce yıl içerisinde olan değişim ve yeniliklerin kat kat fazlası çok kısa sürelerde olmaktadır artık. Hayatın her yönünü kapsayan sanallaşmanın ve bilgisayar/internet teknolojisinin insanların seyahatlerine kadar uzanarak onu da şekillendirmesi doğal olarak kaçınılmaz olur.

Günümüz insanı, eski maceraperest seyyahlar gibi nelerle karşılaşılacağ1 ve ne kadar süreceği bilinmeyen seyahatler yerine; her yönüyle planlanmış, daha az maceralı, yolculuk meşakkati de uçaklar sayesinde pek olmayan seyahatleri ter- 
cih etmektedir. Yola çıkacaklar, önce gidecekleri yerin internet üzerinden genişçe bir araştırmasını yapmakta, bunu yeterli bulmazlarsa, lokal sitelerden daha geniş bilgilere ve çok boyutlu görüntülere ulaşarak, daha önce oraları ziyaret etmiş kişilerin görüşlerine de baş vurarak, gitmeden tanıdıkları(!), sürprizlere de tamamen kapalı -oysa seyahatin en heyecanl yönü sürprizlere açık olabilme özelliğiydibir yeri ziyarete gitmektedirler. Gidilen yer, zaten reklam dünyasının gezilmesi, görülmesi gerekli diye tavsiye ettiği ve kalacakları otellerin, yatakların, yedikleri yiyeceklerin standartları da hemen hemen dünyanın her tarafında küresel markaların standardize ettiği özelliklerin pek de uzağında olamayan yerler olmaktadır.

Güvenlik endişelerinden, kendilerine çizilen rotaların dışına pek çıkılamayan bu yeni seyahat tarzında, seyyahlar, kendilerine gösterilen ötekinin dünyasından küçük ve bilindik bir kısmını görmekle yetinerek ülkesine dönmek zorunda kalırlar. Oysa ötekinin gerçek hayatı, güvenlik duvarlarının/yıldızları bol otellerin dışında, arka sokakların gizli kalmış derinliklerinde, köylerde, kasabalarda, sessizce ve bütün otantikliğiyle akıp gitmektedir (Dinçer, 2011: 126-128).

\section{Mac Farlane ve Osmanlı İnsanı}

Yazar, yirmi yıl arayla iki defa geldiği Osmanlı coğrafyasına diğer seyyahlardan farklı bir gözle bakmayı amaçlayarak yola çıkar. Değişik ülkelerden gelen her bir seyyahın geniş Osmanlı dünyasının bir bölümüne ayna tuttuğunu belirttikten sonra kendisinin geliş zamanının ve eserinde vereceği bilgilerin imparatorluğun çok kritik dönemlerine rastladığı için ayrı bir önemi hak ettiğini özellikle vurgular. İmparatorluğun bazı büyük felaketleri ve sevinçleri bir arada yaşadığı bu dönemlerde, Müslüman tebaanın düşüncelerine yakından tanık olmak, onlarla ilgili en gerçek/doğru bilgileri gücünün zirvesinde olan Britanya'nın hizmetine sunmak Mac Farlane'in ana gayelerinden olur. Yazar, eseri boyunca, siradan bir seyyah olmak yerine, uzak diyarlarda yayılmacı hevesleri olan büyük bir ülkenin gören gözü olarak kendisini konumlandırır.

Birinci yolculuğunun Yunan bağımsızlık hareketlerine ve Rusya'nın Osmanlı Devleti üzerindeki yayılmacı politikalarının arttırdığı dönemlere denk gelmesi; ikinci seyahatin ise Tanzimat sonrası Osmanlı reformları dönemlerine rastlaması, yazarın verdiği bilgilerin önemine önem katar. 
İlk ziyaretinde şahit olduğu adaletsizliklerden, kötü yönetimlerden sonra acılar içinde ölmeye yatmış bir imparatorluğu, yeniden ziyaret etmeyi aklından bile geçirmediğini belirten yazar, Sultan Abdülmecid'in tahta geçmesi ve Mustafa Reşid Paşa'nın vezirliğe gelmesiyle büyük reformların yapıldığına, bir Osmanlı bürokratı tarafından inandırılır. Böylece yirmi yıllık aradan sonra, gerçekten Müslümanlarla gayri-Müslimler arasında eşitliğin sağlandığını, her türlü kötü yönetimlere, zulme ve rüşvete son verilip verilmediğini yerinde görmek için on bir ay sürecek yeni yolculuğuna karar verir. Mac Farlane, bu ziyaretinde Osmanlı yönetimindeki değişik toplulukların, rrkların ve milletlerin yaşam koşullarına daha fazla dikkat çekeceğini özellikle belirtir.

\section{a- Türkler}

Tanzimat reformlarıyla Türkiye'de birçok ilerlemenin olduğunu dinleyen, okuyan Mac Farlane, vapurdan Tophane'nin pis, çamurlu iskelesine iner inmez ilk şoku yaşar. Etraftaki kargaşaya, perişanlığa gözlerini çevirince okuduklarının ve duyduklarının hiç de doğru olmadığını anlamakta gecikmez. Avrupa'da oluşturulan imajla hayalleri süsleyen İmparatorluğun başkentinin caddeleri, düzensizlik ve kirlilik içerisindedir. Sokakları ve döşenen taşları da karman çormandır. İnsanları ise dar sokaklardan gelip geçenlere yol vermeyen, çirkin görünüşlü kişilerdir. Yollarda odun, kereste taşıyan at ve eşekler bolca göze çarpar. Kalabalıklaşmış sokaklar, caddeler 1828 'de görüldüğünden daha kötüdür. Hiç temizlenmeyen kötü kokulu yollar, evlerin önleri, yangınlardan arta kalan çirkin yığınlar, köpek ve fare leşleri 1848 yılı başkent manzaralarıdır. Özellikle geceleri aralıksız duyulan sahipsiz köpeklerin havlamaları, ulumaları, satıcıların bitmeyen çı̆̆ırtkanlıkları, sivrisinek benzeri haşeratların deliksiz uykuya müsaade etmeyen rahatsızlıkları, insana İstanbul'da olduğunu hatırlatır.

Tanzimat sonrası İstanbul'da yaşayan Türkler, önceki dönemlere göre daha uysal, daha sivilize olmuş kişiler olarak anlatılır. Reformların etkisiyle çenelerine kadar düğmelenmiş paltoları ve dar pantolonlarıyla eski görkemli, üsten bakan, kibirli hallerinden eser kalmamıştır. Eskiden, kabadayıca yürüyüşüyle, etrafındakileri hakir gören yüksekten bakışıyla ve kendine has giyimiyle kolayca tanınan Türk, yeni oluşan ortamda sanki bütün bu özelliklerini birer birer kaybetmiş̧ir. 
Şehrin en sessiz ve mütevazı yaşayan kesimi olur, onların eski kural tanımazlıklar1, kabadayılıkları Ermeni sarraflara ve ailelerine geçmiş gibidir.

Bayramlar ve önemli günler dışında, sosyal yaşantıyı sevmeyen bu insanlar, günlerinin büyük bir bölümünü, kahvehanelerde çeşitli tütünler içerek geçirirler. Çok hareketsiz bir yaşamları vardır. Bağdaş kurarak saatlerce sessiz oturmaları en büyük özelliklerindendir. Yüksek bir makama geldikten sonra pek çalışmayan, hareketsizliklerinden dolayı da çabuk şişmanlayan insanlardır. Onların hayatlarında rüşvet de yaygın bir alışkanlıktır.

Sakin ve sessiz hayatları olan Türklerin, ne zaman sinirlenip alevleneceğini kestirebilmek en zor şeylerden birisidir, sanki sinirlendiklerinde ne yapacağı belli olmayan (Mac Farlane, 1829: 190) uyuyan bir aslan gibidirler. Kadınları ise onlarla birlikte dışarılarda hiç gözükmezler, onlara ayrılan dünya, evlerinin içindeki dünyadır. Türklerin etraflarındaki diğer grupların sosyal yaşantılarına katılmaları da nadir görülen şeylerdendir. İzmir'in diğer milletlerden oluşan yapısı sayesinde, buradaki Türklerin diğer bölgelerdeki Türklere göre yaşantılarının Avrupaî tarzlara daha yakın olduğu söylenebilir (Mac Farlane, 1829: 47-49). Onların tutucu olmayan rahat dini yaşantıları, diğer bölge Türkleri tarafından asırlarca üzerlerinden gitmeyecek incitici bir sifatla anılmalarına sebep olur: "Gavur Izmir”.

İzmir çevresindeki yerleşim yerlerinde yaşayan Türklerin yaşam standartları da basittir, daha çok aynı odada yemek yerler, aynı odada yatarlar. Bundan dolayı da bit pire gibi küçük haşeratlar da evlerinden pek eksik olmaz. Misafirlerine karşı da hürmetkârdırlar. Eğer erkekleri evde yok ise misafir de olsa yabancıları evlerine almazlar. Oturma odaları üç tarafı duvarlara dayalı, yerden biraz yükseltilmiş oturma alanından oluşur. Oturdukları odanın duvarlarında, içerisi kullanılmayan çeşitli mutfak eşyalarıyla süslenmiş raflar vardır. Dinlerinden dolayı hoş karşılanmadığı için de insan ve canlı resimlerine duvarlarında pek rastlanılmaz.

Ramazan aylarında gündüzleri sessizdirler. Çarşı pazarlarda da pek ses olmaz, kahvehaneler, kebapçılar, açılmak için iftar vaktini bekler. İftarla birlikte her yer bayram yerine döner. Kebapçılar ve kahvehaneler dolup taşar. Gece boyunca tütünün ve nargilenin dumanları arasında koyu sohbetler yapılır, hikâye anlatıcıların etrafında toplanılır. Yapısal olarak neşeli olmayan Türklerin, Ramazan akşamlarında, çok neşeli bir hale büründükleri görülür. 
Türk çiftçisinin genel özelliği; İmparatorluğun geniş coğrafyasının tamaminda dürüst, iyi huylu zararsız ve biraz da tembel olmalarıdır. Genellikle onlar arasında yol kesme, eşkıyalık ve hırsızlık gibi adi suçlara tenezzül edenler pek görülmemektedir. Son zamanlarda açlığın, yoksulluğun etkisiyle çok az da olsa böyle kötü işlere tenezzül edenler çıkmaya başlar.

\section{b. Rumlar}

Tarihte kendilerine ait büyük bir medeniyete sahip olmalarına rağmen bu millet, Asya’nın iki büyük gücü olan İranlılar ve Osmanlıların baskılarını hep üzerlerinde hissetmişlerdir. 1822 Yunan isyanından önce eğlenceleriyle, balolarıyla, kendilerine has giyim ve yaşam tarzlarıyla İzmir'de problemsiz bir hayat yaşayan Rumların hayatı, bu tarihle birlikte değişir. Neşeli hayatlarından ve geleneksel eğlencelerinden fazla uzaklaşmamalarına rağmen, eski zengin yaşamlarından eser kalmaz. Navarino isyanının kamuoyunda açmış olduğu derin yaralar neticesinde, Türklerden ve onların gözü önünden uzak yaşamanın kendileri için daha güvenli olacağını hissederler. Türkler, Ermeniler ve Yahudilerin aksine onların bütün eğlencelerinin merkezinde kadınlar vardır. Rum kadınlarının güzellikleri de öyle sıradan değildir. İri siyah gözleri, çirkinliğin hiç uğramadığı yüzleri, itinalı makyajlarıyla dikkat çeken güzellikleri, biraz daha titizlik ve bakımla İngiliz saraylarında bile yadırganmayacak dereceye ulaşabilir. Rum erkeklerinin görüntüsü de çirkin değildir. Giyimlerine özen gösterme tarihlerinden gelen ve Türklerden geçen önemli özelliklerinden biridir. Bu civardaki Rum erkeklerinin alkole bağımlılı̆̆ 1 da fazladır. Bunun sebepleri arasında, sürekli korku içerisinde yaşamaları ve efendileri olan Türklerden gördükleri adaletsiz uygulamalar gösterilebilir. Bu dönemde çıkabilecek bir Osmanl1-Rus savaşında, Rum toplumunun duaları hiç şüphesiz içerisinde yaşadıkları ve tebaası oldukları devlet için değil; Rusya'nın kazanması için olacaktır.

İzmir'deki Rumlar ve çocukları, buradaki okullar sayesinde, kendi dillerinden uzaklaşmamaktadırlar; ama İmparatorluk coğrafyasının birçok yerine dağılmış olan Rumlardan bazıları, kendi dillerini bile unutmuşlardır. Bildikleri tek dil ise Türkçedir.

Çeşmedeki Rumların hayatı da 1821-22'de yaşanan kanlı olayların etkisiyle Türklerin onlara dostane olmayan yaklaşımları neticesinde, zorluklarla 
doludur. Bazıları çıkan isyanlarda öldürülmüş, bazıları kaçarak hayatta kalmayı başarabilmiş, bazıları ise özellikle kızlar ve kadınlar, Türklerin eline geçerek ya haremleri ya da köleleri olmuştur. Yazarın anlattığı 1828 yılında, Rumlar, burada sakin bir hayat yaşamalarına rağmen; yıkılan kutsal yerlerin, tarumar edilen evlerin ve Türk erkekleri tarafından alıkonulan kadınlarının hikâyeleri, hafızalarda hep diriliğini korumaktadır.

Çeşme'den Sakız adasına geçen seyyah, burada da Navarino isyanının acı sonuçlarını bütün çıplaklığıyla görür. Rumlara ait kutsal yerler, evler, okullar yerle bir edilmiştir. Bir zamanlar, yaklaşık dört yüz Rum öğrencinin eğitim görebildiği okulun artık binası bile yoktur ve neşeli, cıvıl cıvıl insanlarla dolu olan, her tarafı bağlık bahçelik yerlerde, şimdi az sayıda -yaşanılan korkunç anların izlerini belleklerinde miras olarak saklayan- mutsuz Rumlar vardır.

\section{c. Ermeniler}

İmparatorluğun değişik bölgelerinde bulunan Ermenilerin yaşam tarzlarında, fazla farklılıklar görülmez. Yaşam şekilleri, Türklerin yaşam şekilleriyle paralellikler gösterir, onlar da yemeklerini yer sofralarında yerler, çatal ve bıçak gibi temizlik göstergesi aletleri kullanmak yerine, kirli elleri ve parmakları, onların en büyük yardımcılarıdır, sofralarında. Kadınlarının, evin dışındaki dünyalarda, gözlerinden başka yerlerini görebilmek pek olası değildir. Ev içinde de kadınlar bir eşten ziyade erkeğinin yanında sanki bir hizmetçi konumundadır. Hem aile içerisinde hem çarşı pazarda kullandıkları dil de kendi dillerinden ziyade Türkçedir.

Osmanlı coğrafyasında hamallık gibi ağır işlerde kullanılan, sanattan edebiyattan anlamayan, yüzleri de pek gülmeyen bu kaba yapılı insanlar, zamanla değerli madenlerin ticaretinde çok başarılı olmuşlardır. Hatta bankerlikte ve sarraflıkta Yahudilerden daha da ileri giderek, sultanın ve paşaların nezdinde hayli yüksek mevkilere ulaşmışlardır. "Yalnız Osmanlıda en yükssek makamların en tehlikeli makamlar olduğunu ve yapılan en küçük hatalarda da kellerin gittiğini unutmamak da gerekir.” Cümlesi ile yazar, okuyucusunu uyarma ihtiyacından uzak kalamaz.

Seyahatname boyunca yazarın, Rumlara karşı yaklaşımının hep olumlu olmasına rağmen; Ermeni toplumuna ve insanlarına karşı aynı yaklaşımı görebil- 
mek mümkün değildir. Ona göre Şarkın en kaba saba toplumu Ermenilerdir; hatta Türklerden bile daha kötü daha zalim insanlardır. Sadece kendi menfaatleri için yaşayan, bu bencil insanlar, çevrelerindeki diğer topluluklara saygıları da yoktur; ellerinde firsatları olsa onlara yaşam hakkı bile vermeyebilirler (Mac Farlane, 1829: 196-197).

\section{d. Yahudiler}

Osmanlı coğrafyasında en çok horlanan topluluklardan birisinin de Yahudi toplumu olduğunu belirtiyor yazar. Onlar daha çok başkalarının işlerini yapmakla geçinirler. Askerlik, savaş ve tarımsal işlerden hep uzak yaşamayı tercih ederler. Onların tarımsal aletlerle toprakta çalıştığını görebilmek zordur. Diğer topluluklar gibi farklı giyim tarzları olan Yahudi topluluğun en belirgin özelliklerinden birisi de fazlaca korkak olmalarıdır. Ancak İngiltere’ de yaşayanlarının bu derece korkak olmadığından yola çıkarak tedirginliklerinin kaynağının buralarda maruz kaldıkları baskılar olduğunu iddia eder Mac Farlane. Kullandıkları diller ise bozuk İspanyolcalarının yanında, efendilerinin dili olan Türkçe, zaman zaman da Rumcadır. Genelde üzgün insanlar olarak kabul edilseler de sosyal ve neşeli yaşantıları vardır. Nişan törenleri ve evlilikleri 12-15 gibi erken yaşlarda olmaktadır. Vazgeçemedikleri en meşhur, geleneksel yiyeceklerinin zeytin, zeytinyağı ve havyar olması da başka bir özellikleridir.

\section{Sonuç}

Toplumların kendi dünyaları dışındaki yaşamlara olan ilgisi hiçbir zaman azalmaz. Asırlarca bu dünyalara açılan pencereler, genellikle seyyahların yazdıkları eserler aracılığıyla olur, onlar sayesinde toplumlar kendi dışındaki dünyaları tanımaya başlar ve o dünyalara karşı merakları artar. Bu tanıtımda toplumların gören gözleri oldukları için seyyahlara, büyük görevler düşer. Birinci görevleri, gezip gördükleri yeni yerleri, toplumlarına olabildiğine objektif bir şekilde tanıtmak, onların doğru bilgilerle beslenmelerine katkı sağlamak olmalıdır. Yalnız tarihsel süreç içerisinde, ortaya konan eserlere bakıldığında, bazen seyyahın amaçlarına göre eserinin doğru bilgilerden ziyade; ön yargılı, yanlış bilgilerle de dolu olduğu görülmektedir. Seyyah, mensubu olduğu ülkenin veya dini cemaatin 
çıkarları doğrultusunda, gerçekleri değiştirebilmekte veya kitabının daha fazla okunmasını sağlayabilmek için zaman zaman onu, hayali, egzotik veya erotik bilgilerle süsleyebilmektedir.

Kendi dışındaki coğrafyalar ve kültürler hakkında elde ettiği çok yönlü bilgilerle 19. yüzyıla giren Batı'nın -özellikle sayıları çoğalan seyyahların “öteki” hakkında elde ettiği önemli bilgiler sayesinde- ekonomik ve kültürel gelişmelerinde de bir hızlanma görülür. Gücünün zirvesine ulaşan, karşısında bu güce eşdeğer bir oluşum da olmayan Batı için dünyanın diğer bütün coğrafyaları, hükümleri altına alınacak, tarihî ve kültürel değerleri yeni bir anlayışla yorumlanarak kontrolleri altına girmesi gerekecek bir arzu nesnesine dönüşür.

Bu dönemlerde, yirmi y1l arayla iki defa Osmanlı ülkesine gelen Mac Farlane, şahit olduklarını, gözlemlerini yazdığı dört ciltlik kitabında dile getirir. Ona göre; yıkılmaya doğru büyük bir hızla giden İmparatorluğun aksayan yönleri çok fazladır ve bu şartlar altında uzun süre yaşaması imkânsızdır. Osmanlı yöneticileri iş yapmayı sevmeyen, tembel insanlardır, rüşvet onlar arasında fazla yaygındır, azınlıklara karşı iyi davrandıkları da söylenemez. Türk erkekleri, çalışmayı değil; zaman öldürmeyi seven insanlardır. Hayvanlara karşı çok merhametli olmalarına rağmen, aynı merhameti insanlara göstermemeleri şaşılacak şeylerdendir. Kadınları ise hâlâ eşlerinin yanlarında değil; ev içlerinde hapis hayatı yaşamaktadır. Coğrafi olarak çok güzel şekilde yaratılmış olan başkentleri ise pislik içerisinde, perişan bir vaziyettedir. 


\section{Kaynakça}

Barkeretal, Francis (1984) Europe and Its Others, The University of Essex.

Behdad, Ali (2007), Kolonyal Çözülme Çă̆ında Oryantalizm, (çev: Sibel Erduman - Berkay Ersöz), Chiviyazıları Yayınevi, İstanbul.

Beyhan, Mehmet Ali (2013),Geçmişten Günümüze Seyahatler ve Seyahatnameler, Kitabevi Yayınları, İstanbul.

Berman, Marshall (2017), Katı Olan Her Şey Buharlaşıyor, (çev: Ümit Altuğ-Bülent Peker), İletişim Yayınları, İstanbul.

Bulut, Yücel (2010), Oryantalizmin Kısa Tarihi, Küre Yayınları, İstanbul.

Carrington, Dorothy (1947,) The Traveller's Eye, The Pilot Press, London.

Çağan, Kenan (2011), "Seyahatten Turizme Bir Devinim Hikâyesi”, Hece - Gezi Özel Sayısı, S. $174-175-176$, s. $62-69$.

Çağan, Kenan (2019), Postmodernizm ve Mahremiyetin Dönüşümü, Pruva Yayınları, Ankara.

Derin, Süleyman (2006), İngiliz Oryantalizmi ve Tasavvuf, Küre Yayınları, İstanbul.

Dinçer Ateş, "Sanal Dünyada Sanal Geziler ve Gezici/Gezi Yazısı ve Kültürüne Etkileri”, Hece - Gezi Özel Saylsi, S. 174-175-176, 2011, s. 126-128.

Doğan, Muhittin (2018), "Seyahat/Avrupalı Seyyahlar ve Yakın Doğu (s. 229-255)", Necat Birinci Armağanı, Berikan Yayınevi, Ankara.

Eravc1, Mustafa (2010), Avrupa'da Türk Imajl, Çizgi Kitabevi, İstanbul.

Fusseli, Paul (1980), Abroad: British Literary Travelling Between The Wars, Oxford.

Gökçe, Orhan-Gülise (2011), Avrupa'da İslam ve Türk İmajı, Birleşik Yayınevi, Ankara.

Güler, İbrahim (2013), Geçmişten Günümüze Seyahatler ve Seyahatnameler, Kitabevi Yayınları, İstanbul.

Irwin, Robert (2008), Oryantalistler ve Düşmanları, (çev: Bahar Tırnakçı), Yapı Kredi Yayınları, İstanbul.

Kabbani, Rana (1986), Europe's Myths of Orient: Devise and Rule, Indiana University Press, Basingstoke.

Kahf, Mohja (2006), Batı Edebiyatında Müslüman Kadın Imajı, (çev: Yeşim Sezdirmez), Küre Yayınları, İstanbul.

Kalın, İbrahim (2016), Ben, Öteki ve Ötesi, İslam-Batı İlişkiler Tarihine Giriş, İnsan Yayınları, İstanbul,

Kiernan, V. G. (1969) The Lord of Humankind, Black Man, Yellow Man and White Man in an Age of Empire, Boston. 
Lowe, Lisa (1991), Critical Terrains: French and British Orientalism, Ncrol, London.

Löschburg, Winfried (1998), Seyahatin Kültür Tarihi, (çev: Jasmin Traub), Dost Kitabevi, Ankara.

Macfarlane, Charles (1829), Constantinople in 1828: A Residence of Sixteen Months in the Turkish Capital and Provinces with an Account of the Present State of the Naval and Military Power and of the Resources of the Ottoman Empire, C. I-II, London, 1829.

Macfarlane, Charles (1850), Turkey and its Destiny: The Results of Journeys Made in 1847 and 1848 to Examine into the State of that Country, C. I-II, London, 1850.

Melman, Billie (1992), Women's Orients: English Women and the Middle East, Macmillan, Basingstoke.

Mills, Sara (1991), Discourses of Difference: An Analysis of Women's Travel Writing and Colonialism, Routledge, London.

Parla, Jale (2012), Efendilik, Şarkiyatçılık, Kölelik, İstanbul, İletişim Yayınları.

Porter, Dennis (1991), Haunted Journeys, Desir and Transgression in Auropean Travel Writing, Princeton University Press.

Said, Edward (1995), Orientalism, Penguen, London.

Thompson, Carl (2011), Travel Writing, Routledge, London,

Yeğenoğlu, Meyda (2003), Sömürgeci Fanteziler, Oryantalist Söylemde Kültürel ve Cinsel Fark, Metis Yayınları, İstanbul. 